\title{
Harvest Number and Growing Season Effects on Quality and Health Related Compounds in Parsley
}

\author{
Ozlem Alan ${ }^{1 *}$, Ayse Betul Avci ${ }^{1}$, Refiye Refika Akcali Giachino² \\ ${ }^{1}$ Ege University, Odemis Vocational School, 35760, Izmir, TURKEY \\ ${ }^{2}$ Ege University, Faculty of Agriculture, Department of Field Crops, 35100, Bornova-Izmir, TURKEY
}

\begin{abstract}
Background and Purpose: Parsley is mostly grown outdoors and harvested seasonally. Farmers in many parsley producing countries, especially in the temperate region such as Turkey usually prefer spring sowings (summer growing season-SGS) and fall sowings (winter growing season-WGS) for open field production. Parsley can be usually harvested 4-8 times in temperate climates, if some special precautions are taken it may be 1015 times. In arid, hot and cold climate regions, 2-4 harvests can be obtained. Material and Methods: Seed material of parsley obtained from regional farmers. Two growing cycles per year, i.e. for summer growing season (SGS) and winter growing season (WGS) production and harvest number, have been investigated for their effects on quality and health promoting compounds of parsley such as dry matter content (DMC), color values, chlorophylls (Chl), vitamin C, antioxidant activity and total phenol content. Results: Statistically significant differences were identified for DMC, color values, $\mathrm{Chl}$ and total phenol between harvest numbers for both the growing seasons. On the other hand, vitamin $C$ and antioxidant activity were not affected significantly by harvest numbers for both the growing seasons. DMC increased with increasing harvest numbers for only the SGS. Darkest leaves were obtained from fourth harvest for the SGS; from second harvest for the WGS. First harvest had the highest $\mathrm{Chl}$ ' $\mathrm{a}$ ' $+{ }^{\prime} \mathrm{b}^{\prime}$ with $52.87 \mathrm{mg} / 100 \mathrm{~g}$ for the SGS; second harvest had the highest Chl ' $a$ ' + ' $b^{\prime}(40.36 \mathrm{mg} / 100 \mathrm{~g})$ for the WGS. Total phenol content decreased with increasing harvest numbers for the SGS. Contrarily to the SGS, total phenol content increased slightly with increasing harvest numbers by $5 \%$ for the WGS. Conclusion: It can be concluded that depending on harvest numbers either an increase, a decrease or no effect in quality and health related compounds of parsley seemed to occur. The SGS may be taken more seriously, since it creates a better environment for the expression of different quality traits as compared to the WGS.
\end{abstract}

Keywords: Petroselinum crispum L., Dry Matter Content, Chlorophylls, Antioxidant Activity, Total Phenol.

\section{INTRODUCTION}

Parsley (Petroselinum crispum L.) belong to the Apiaceae family and is mostly grown outdoors and harvested seasonally. It's popular fresh herbs in the world for aromatic and valuable biochemical compounds ${ }^{1}$ Parsley leaves are rich in $\mathrm{C}$ and $\mathrm{K}$ vitamins, and it used to treat common illnesses as digestive system problems, hair and scalp problems and diabetes, blood pressure promoter and fertility regulation, abortifacient. ${ }^{2-5}$ The origin of parsley is from Mediterranean region, but today is cultivated wherever of the world. Also, parsley is a traditional leafy green vegetable and commercially cultivated as an annual plant in many parts of the world. ${ }^{6}$

Several studies have been reported that quality and health realted compounds in vegetables depends on many factors, such as variety, cultivation conditions and the degree of ripeness at harvest. Biochemical value changes of dill during different stage of growth were determined in Finland. ${ }^{7}$ Novac $^{8}$ showed the influence of genotype
DOI: 10.5530/ijper.51.3s.29 Correspondence: Ozlem alan, Ege University, Odemis Vocational School, 35760, Izmir, TURKEY.

Phone no: +90 5335403770 E-mail: ozlemgorgen@ yahoo.com

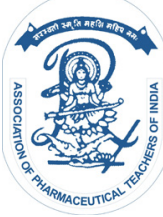

www.ijper.org 
to carotenoids and chlorophylls accumulation in parsley leaves. Seasonal differences in composition and antimicrobial activity of volatile compounds were determined in parsley. ${ }^{9}$

Parsley is marketed continuously throughout the year as a fresh market culinary green. To do so, some growers will seed three times per year. A summer sowing is fall harvested, a fall sowing may overwinter with harvest in the spring, and spring sowings are harvested in the late spring and early summer. ${ }^{10}$ In Turkey, the acreage of parsley grown is 49.3 thousands decare and the amount of parsley production is nearly 58.2 tones in $2016 .{ }^{11}$ Parsley is produced both open field and under cover and open field grown parsley represent about $97 \%$ of the total quantity in $2016 .{ }^{11}$

Farmers in many parsley producing countries, especially in the temperate region such as Turkey usually prefer spring sowings (summer growing season-SGS) and fall sowings (winter growing season-WGS) for open field production. Parsley can be usually harvested 4-8 times in temperate climates, if some special precautions are taken it may be 10-15 times. In arid, hot and cold climate regions, $2-4$ harvests can be obtained. ${ }^{12}$

Several studies have been reported on changes in parsley quality and some health related compounds under different environments; there is so far no data available on how growing season and harvest number affect quality traits of parsley. The objective of this research was to evaluate the effects of harvest number and growing season on quality traits and health related compounds in parsley.

\section{MATERIAL AND METHODS}

The experiment was conducted during 2014 and 2015 in the experimental fields of Odemis Vocational School at Ege University, Izmir, Turkey (latitude $38^{\circ} 12^{\prime} \mathrm{N}$, longitude $27^{\circ} 52^{\prime} \mathrm{E}$, altitude $111 \mathrm{~m}$ ). The soil was loamy sand with $1 \%$ organic matter, $0.03 \%$ total salt, $2.7 \%$ lime and $\mathrm{pH}$ 7.15. Seed material of parsley obtained from regional farmers. The trials were set up in randomised complete block design, with three replications. Each trial was $5.40 \mathrm{~m}^{2}$. Seeds were sown on March 24 in 2014 for the SGS and on September 20 in 2014 for the WGS, in a spacing of $30 \mathrm{~cm} \times 2-3 \mathrm{~cm}$. Four harvests were carried out for the SGS on 29 May, 03 July, 22 July and 11 September in 2014, respectively. Two harvests were performed for the WGS on 14 April and 05 May in 2015. The drip irrigation was applied as needed and weeds were controlled mechanically by hand. No fungicide or insecticide was applied during cultivation.
When the parsley leaves reached harvest maturity, ${ }^{12}$ leaves from the centre of each replication were harvested by cutting in the morning. Then, the leaves were taken to the processing laboratory immediately in cool boxes. They were washed first with tap water, then twice with deionized water. Excess water was removed with a domestic salad spinner and the following experiments were conducted.

Dry Matter Content (DMC) and leaf color was determined as indicated by Tuncay et al. ${ }^{13} \mathrm{~L}$-ascorbic acid content was measured in the filtrate by using 2,6-dichloroindophenol according to the titrimetric method. ${ }^{14}$ For chlorophylls (Chl), samples were prepared as indicated by Arnon. ${ }^{15} \mathrm{Chl}$ determinations were carried out by reading absorbance at 645,663 and $652 \mathrm{~nm}$ in a spectrophotometer (CarryBio 100, Varian, Australia). Chl a and b and total $\mathrm{Chl}$ contents were calculated by Lichtenthaler and Welbaum. ${ }^{16}$ Total phenol and antioxidant activity, leaf extracts were prepared according to Thaipong et $a l^{17}$ with some modifications for total phenolic content and antioxidant activity (in methanol extract) analysis. Total phenolic content was determined by the FolinCiocalteu method according to the method of Zheng and Wang, ${ }^{18}$ with an incubation time of 120 minutes for color development. The absorbance was measured at $725 \mathrm{~nm}$ using a spectrophotometer and the results were expressed as milligram gallic acid equivalent (GAE) per 100 gram of fresh weight (FW) with reference toa gallic acid $(0-0.1 \mathrm{mg} / \mathrm{mL})$ standard curve. The ferric reducing ability of plasma (FRAP) assay was performed as previously described by Benzie and Strain, ${ }^{19}$ where reductants ("antioxidants") in the samplereduce Fe (III)/tripyridyltriazine complex to a blue ferrousform, with an increase in the absorbance at $593 \mathrm{~nm}$. The final results are expressed in $\mu$ moltrolox equivalents (TE) $/ \mathrm{gFW}$, with reference to a trolox $(25-500 \mu \mathrm{mol})$ standard curve.

All collected data were subjected to the analyses of variance (ANOVA) by using SPSS ${ }^{\circledR}$ version 19 statistical software on an $\mathrm{IBM}^{\circledR}$ computer. Significant differences among the groups were determined by Duncan's multiple range test at $P \leq 0.05$.

\section{RESULTS \& DISCUSSION}

DMC was significantly affected by harvest numbers in SGS $(p \leq 0.01)$ but non-significant differences were found in WGS (Table 1). DMC increased with increasing harvest numbers for the SGS. Fourth harvest had the highest DMC with 20.2\% while first harvest (14.5\%) had the lowest. According to mean values, the WGS had higher dry matter content by $50 \%$ compared to the SGS. DMC values are in close agreement with earlier 


\section{Table 1: Changes in DMC and color of parsley depending upon different harvest numbers in both the growing seasons.}

\begin{tabular}{|c|c|c|c|c|}
\hline \multicolumn{5}{|c|}{ Parsley summer } \\
\hline Factor & DMC (\%) & L & Chroma & Hue \\
\hline First harvest & $14.5 \mathrm{c}$ & $34.9 \mathrm{bc}$ & $23.2 \mathrm{~b}$ & $122.8 \mathrm{a}$ \\
\hline Second harvest & $15.7 \mathrm{c}$ & $36.9 \mathrm{~b}$ & $24.9 \mathrm{~b}$ & $122.2 \mathrm{ab}$ \\
\hline Third harvest & $18.3 \mathrm{~b}$ & $40.2 \mathrm{a}$ & $27.4 \mathrm{a}$ & $123.3 \mathrm{a}$ \\
\hline Fourth harvest & $20.2 \mathrm{a}$ & $33.0 \mathrm{c}$ & $29.2 \mathrm{a}$ & $121.2 \mathrm{~b}$ \\
\hline Mean & 17.1 & 36.2 & 26.2 & 122.4 \\
\hline LSD (\%5) & $1.90^{* *}$ & $2.66^{* *}$ & $2.44^{* *}$ & $1.40^{*}$ \\
\hline \multicolumn{5}{|c|}{ Parsley winter } \\
\hline Factor & DMC (\%) & L & Chroma & Hue \\
\hline First harvest & 25.1 & $38.9 \mathrm{a}$ & $35.6 \mathrm{a}$ & $118.7 \mathrm{~b}$ \\
\hline Second harvest & 26.3 & $27.2 \mathrm{~b}$ & $22.9 \mathrm{~b}$ & $125.0 \mathrm{a}$ \\
\hline Mean & 25.7 & 33.1 & 29.3 & 121.8 \\
\hline LSD (\%5) & $\mathrm{ns}$ & $5.93^{*}$ & $5.32^{* *}$ & $5.33^{*}$ \\
\hline
\end{tabular}

*,**: statistically significant at $\mathrm{p} \leq 0.05, \mathrm{p} \leq 0.01$, respectively

Within each column, same letter indicates the absence of significant differences at $p=0.05$

\begin{tabular}{|c|c|c|c|c|c|c|}
\hline \multicolumn{7}{|c|}{ Parsley summer } \\
\hline Factor & $\begin{array}{c}\text { Chl 'a' } \\
\text { (mg/100 g) }\end{array}$ & $\begin{array}{c}\text { Chl 'b' } \\
\text { (mg/100 g) }\end{array}$ & $\begin{array}{c}\text { Chl 'a' + Chl 'b' } \\
(\mathrm{mg} / 100 \mathrm{~g})\end{array}$ & $\begin{array}{l}\text { Vitamin C } \\
(\mathrm{mg} / 100 \mathrm{~g})\end{array}$ & $\begin{array}{c}\text { Antioxidant } \\
\text { activity } \\
(\mu \mathrm{mol} \text { TE/g FW) }\end{array}$ & $\begin{array}{c}\text { Total } \\
\text { Phenolic contents } \\
\text { (mg GAE/100 g FW) }\end{array}$ \\
\hline First harvest & 36.9 a & $15.9 a$ & $52.9 \mathrm{a}$ & 166.6 & 9.3 & $125.9 \mathrm{a}$ \\
\hline Second harvest & $22.8 \mathrm{c}$ & $11.4 \mathrm{~b}$ & $34.2 \mathrm{~d}$ & 168.5 & 8.7 & $115.6 \mathrm{~b}$ \\
\hline Third harvest & $27.1 \mathrm{bc}$ & $12.6 a b$ & $39.7 \mathrm{c}$ & 167.5 & 8.6 & $115.5 b$ \\
\hline Fourth harvest & $31.5 a b$ & $15.5 \mathrm{a}$ & $46.8 \mathrm{~b}$ & 171.2 & 8.2 & $103.6 \mathrm{c}$ \\
\hline Mean & 29.6 & 13.9 & 41.4 & 168.4 & 8.7 & 115.1 \\
\hline LSD (\%5) & $6.83^{*}$ & $3.33^{*}$ & $5.23^{* *}$ & ns & ns & $7.79^{* *}$ \\
\hline \multicolumn{7}{|c|}{ Parsley winter } \\
\hline Factor & $\begin{array}{c}\text { Chl 'a' } \\
\text { (mg/100 g) }\end{array}$ & $\begin{array}{c}\text { Chl 'b' } \\
\text { (mg/100 g) }\end{array}$ & $\begin{array}{c}\text { Chl 'a' + Chl 'b' } \\
(\mathrm{mg} / 100 \mathrm{~g})\end{array}$ & $\begin{array}{l}\text { Vitamin C } \\
(\mathrm{mg} / 100 \mathrm{~g})\end{array}$ & $\begin{array}{c}\text { Antioxidant } \\
\text { activity } \\
(\mu \mathrm{mol} \text { TE/g FW) }\end{array}$ & $\begin{array}{c}\text { Total } \\
\text { Phenolic contents } \\
\text { (mg GAE/100 g FW) }\end{array}$ \\
\hline First harvest & $14.4 \mathrm{~b}$ & 9.9 & $24.2 b$ & 164.4 & 9.3 & $111.6 \mathrm{~b}$ \\
\hline Second harvest & $27.8 \mathrm{a}$ & 12.6 & $40.4 \mathrm{a}$ & 162.7 & 9.1 & $117.1 \mathrm{a}$ \\
\hline Mean & 21.1 & 11.0 & 32.3 & 163.7 & 9.2 & 114.3 \\
\hline LSD (\%5) & $12.35^{*}$ & ns & $4.42^{* *}$ & ns & ns & $4.04^{*}$ \\
\hline
\end{tabular}

$*, * *$ : statistically significant at $p \leq 0.05, p \leq 0.01$, respectively. Within each column, same letter indicates the absence of significant differences at $p=0.05$

report of Karkleliene et al who investigated DMC of different parsley cultivars.

Leaf lightness values were significantly affected by harvest numbers in both the growing seasons (Table 1). Third harvest had the highest lightness value for the
SGS while first harvest had the highest for the WGS. Harvest numbers had significant effect on chroma and hue values at $(p \leq 0.01),(p \leq 0.05)$ respectively in both the growing seasons. Plants grown in SGS had lighter coloured leaves compared to those grown in WGS. 
Harvest numbers had significant effect on Chl ' $a$ ' and Chl 'a' + Chl 'b' at $(\phi \leq 0.05),(p \leq 0.01)$ respectively in both the growing seasons (Table 2). Chl 'b' was significantly affected by harvest numbers in SGS $(p \leq 0.05)$ but non-significant differences were found in WGS. The highest Chl ' $\mathrm{a}$ ' was obtained from first harvest (36.9 $\mathrm{mg} / 100 \mathrm{~g})$, followed by fourth harvest (31.5 $\mathrm{mg} / 100 \mathrm{~g}$ ) in SGS. In WGS, the highest Chl 'a' was attained from second harvest $(27.8 \mathrm{mg} / 100 \mathrm{~g})$. First and fourth harvests had 15.9 and $15.5 \mathrm{mg} / 100 \mathrm{~g} \mathrm{Chl} \mathrm{'b}$ ' respectively, which were significantly higher than other harvests in SGS. According to mean values, the SGS increased Chl 'a', Chl 'b' and Chl 'a' + Chl 'b' by an average of $40 \%, 26 \%$ and $28 \%$, respectively in comparison to the WGS. Novac ${ }^{8}$ showed the influence of genotype to chlorophylls accumulation in parsley leaves. The amount of chlorophylls reached from 0.6 to $3.9 \mathrm{mg} / \mathrm{g}$.

Harvest numbers had no significant effect on vitamin $\mathrm{C}$ and antioxidant activity neither in the SGS nor in the WGS (Table 2). Vitamin $C$ values changed between $166.6 \mathrm{mg} / 100 \mathrm{~g}$ (first harvest) and $171.2 \mathrm{mg} / 100 \mathrm{~g}$ (fourth harvest) in SGS; between $162.7 \mathrm{mg} / 100 \mathrm{~g}$ (second harvest) and $164.4 \mathrm{mg} / 100 \mathrm{~g}$ (first harvest) in WGS. According to mean values, vitamin $\mathrm{C}$ of SGS was slightly higher by $3 \%$ compared to WGS. Our vitamin C results are similar to the results of Karkleliene et al. Antioxidant activity values changed between $8.2 \mu \mathrm{mol}$ $\mathrm{TE} / \mathrm{g}$ FW (fourth harvest) and $9.3 \mu \mathrm{mol} \mathrm{TE} / \mathrm{g}$ FW (first harvest) in SGS; between $9.1 \mu \mathrm{mol}$ TE/g FW (second harvest) and $9.3 \mu \mathrm{mol}$ TE/g FW (first harvest) in WGS. According to mean values, the WGS had slightly higher antioxidant activity by $6 \%$ compared to the SGS.

Total phenol content of SGS $(p \leq 0.01)$ and WGS $(\phi \leq 0.05)$ were affected significantly by harvest numbers. Total phenol contents decreased with increasing harvest numbers and first harvest had the highest total phenol with $125.9 \mathrm{mg}$ GAE/100 $\mathrm{g}$ FW for the SGS. Contrarily to the SGS, total phenol content increased slightly with increasing harvest numbers by $5 \%$ for the WGS. According to mean values, the SGS had nearly similar total phenol contents with the WGS.

\section{CONCLUSION}

It can be concluded that depending on harvest numbers either an increase, a decrease or no effect in quality and health related compounds of parsley seemed to occur. Harvest numbers had no effect on vitamin $C$ and antioxidant activity of parsley for both the growing seasons. The SGS creates a better environment as compared to the WGS. Growing conditions for each harvest (first, second, etc.) may induce differences in quality traits and health-related compounds of parsley rather than harvest number and growing season.

\section{ACKNOWLEDGEMENT}

This research was supported by Ege University Science and Technology Center, Izmir, Turkey (grant number: 2014/OMYO/002).

\section{CONFLICT OF INTEREST}

Authors declare that they have no conflict of interest.

\section{ABBREVIATION USED}

SGS: Summer growing season; WGS: Winter growing season; DMC: Dry matter content; Chl: Chlorophylls; Chl 'a': Chlorophyll 'a'; Chl 'b': Chlorophyll 'b'; FW: Fresh weight; GAE: Gallic acid equivalent; FRAP: The ferric reducing ability of plasma.

\section{REFERENCES}

1. Karklelienè $R$, Dambrauskienè $E$, Juškevičienè $D$, Radzevičius $A$, Rubinskienè M, Viškelis P. Productivity and nutritional value of dill and parsley. Hort. Sci. (Prague) 2014;41:131-7.

2. Anonymus. http://www.nutrition-and-you.com/parsley.html. 2017; (Access: April, 2017).

3. Abdelhalim A, Aburjai T, Hanrahan J, Abdel-Halim H. Medicinal plants used by traditional healers in Jordan, the Tafila region. Pharmacognosy Magazine 2017;13(49):95-101.

4. Kumar D, Kumar A, Prakash O. Potential antifertility agents from plants: A comprehensive review. Journal of Ethnopharmacology. 2012;140(1):1-32.

5. González JA, García-Barriuso M, Amich F. Ethnobotanical study of medicinal plants traditionally used in the Arribes del Duero, western Spain. Journal of Ethnopharmacology. 2010;131(2):343-55.

6. Mohammad HF, Zahra A, Mohammad RSA, Roja R, Fatemeh F. Parsley: a review of ethnopharmacology, phytochemistry and biological activities. Journal of Traditional Chinese Medicine 2013;33(6):815-26.

7. Huopalahti R, Lahtinen R, Hiltunen R, Laakso I. Studies on the essential oils of dill herb Anethum graveolens L. Flavour and Fragrance Journal. 1988;3:121-5.

8. Novac T. Content of nitrates and pigments in leaves of some parsley cultivars grown in greenhouse. Bulletin UASVM Horticulture 2011;68:261-264.

9. Vokk R, Lõugas K, Kravets M. Dill (Anethum graveolens L.) and parsley (Petroselinum crispum Mill.) Fuss) from Estonia: seasonal differences in essential oil composition. Agronomy Reasearch 2011;9(Spl issue 2):S515-20.

10. Anonymus. https://www.wifss.ucdavis.edu/wp-content/.../10/Parsley_PDF. pdf. 2017; (Access: April, 2017).

11. TSI. Turkish Statistical Institute. https://biruni.tuik.gov.tr/bitkiselapp/bitkisel. zul. 2017; (Access: April, 2017).

12. Vural H, Esiyok D, Duman I. Vegetable Culture (Vegetable Growing). Aegean University, Faculty of Agriculture, Department of Horticulture. 2000;440 p.

13. Tuncay Ö, Eşiyok D, Yağmur B, Okur B. The Effect of Nitrogen Sources on Yield and Quality of Salad Rocket Grown in Different Months of the Year. Journal of Plant Nutrition. 2011;4(4):477-91.

14. AOAC. Official Methods of Analysis, 1995;16th edn (Arlington, Virginia, USA: AOAC).

15. Arnon DI. Mineral Nutrition of Plants. Annual Review of Biochemistry. 1943;12:493-528.

16. Lichtenhaler HK, Wellburn AR. Determination of total carotenoids and chlorophylls a, b and extract in different solvents. Biochemical Society Transactions 1983;11:591 p. 
17. Thaipong K, Boonprakob V, Crosby, Cisneros-Zevallos L, Byrne DH. Comparison of ABTS, DPPH, FRAP, and ORAC assays for estimating antioxidant activity from guava fruit extracts. J Food Comp Anal. 2006;19(6):669-75.
18. Zheng W, Wang SY. Antioxidant Activity and Phenolic Compounds in Selected Herbs. J. Agric. Food Chem. 2001;49(11):5165-70.

19. Benzie IFF, Strain JJ. The Ferric Reducing Ability of Plasma (FRAP) as a Measure of 'Antioxidant Power': the FRAP Assay. Analytical Biochemistry. 1996;239(1):70-76.

\section{PICTORIAL ABSTRACT}

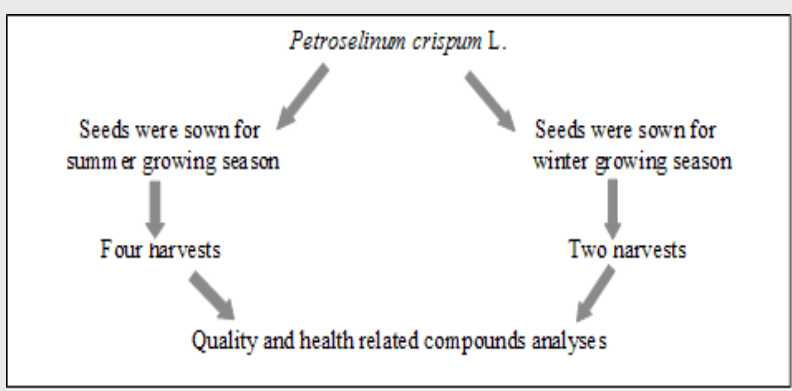

\section{ABOUT AUTHORS}

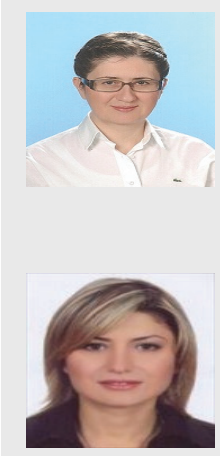

Dr. Ozlem Alan: Assist. Prof. Dr. at Odemis Vocational School of Ege University, 35760 Izmir, TURKEY. Interested in Vegetable Growing and Quality, Seed Production and Quality.

Dr. Ayse Betul Avci: Assoc. Prof. Dr. at Odemis Vocational School of Ege University, 35760 Izmir, TURKEY. Interested in Cultivation on Medicinal and Aromatic Plants and Essential Oils.

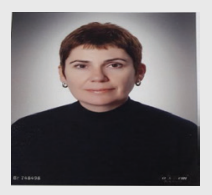

Dr. R. Refika Akcali Giachino: Dr. at Faculty of Agriculture, Deparment of Field Crops of Ege University, 35100, Izmir, TURKEY. Interested in Plant Moleculer Biology, Plant Breeding, Medicinal and Aromatic Plants

\section{SUMMARY}

- Parsley (Petroselinum crispum L.) is a popular herb for aromatic and valuable biochemical compounds.

- It's also a traditional leafy green vegetable and ccommercially cultivated as an annual plant in Turkey.

- Farmers in many parsley producing countries, especially in the temperate region such as Turkey usually prefer spring sowings (summer growing season) and fall sowings (winter growing season) for open field production.

- Parsley can be usually harvested 4-8 times in temperate climates. In arid, hot and cold climate regions, 2-4 harvests can be obtained.

- Two growing cycles production and harvest number, have been investigated for their effects on quality and health promoting compounds of parsley such as dry matter content, color values, chlorophylls, vitamin $\mathrm{C}$, antioxidant activity and total phenol content.

- Dry matter content, color values, chlorophylls and total phenol content were significantly affected by harvest numbers for both the growing seasons.

- Vitamin C and antioxidant activity were not affected significantly by harvest numbers for both the growing seasons.

- It can be concluded that depending on harvest numbers either an increase, a decrease or no effect in quality and health related compounds of parsley seemed to occur. The summer growing season may be taken more seriously, since it creates a better environment for the expression of different quality traits.

Cite this article: Alan $O$, Avci AB, Akcali Giachino RR. Harvest Number and Growing Season Effects on Quality and Health Related Compounds in Parsley. Indian J of Pharmaceutical Education and Research. 2017;51(3)Suppl:S276-80. 